\title{
G

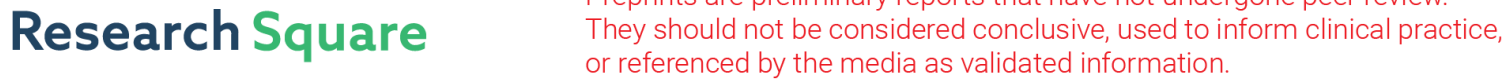 \\ The Clinical Characteristics and Outcomes of Incidentally Discovered Glioblastoma
}

\section{Daisuke Kawauchi}

National Cancer Center Hospital: Kokuritsu Gan Kenkyu Center Chuo Byoin

\section{Makoto Ohno}

National Cancer Center Hospital: Kokuritsu Gan Kenkyu Center Chuo Byoin

Mai Honda-Kitahara

National Cancer Center Research Institute: Kokuritsu Gan Kenkyu Center Kenkyujo

Yasuji Miyakita

National Cancer Center Hospital: Kokuritsu Gan Kenkyu Center Chuo Byoin

Masamichi Takahashi

National Cancer Center Hospital: Kokuritsu Gan Kenkyu Center Chuo Byoin

\section{Shunsuke Yanagisawa}

National Cancer Center Hospital: Kokuritsu Gan Kenkyu Center Chuo Byoin

\section{Yukie Tamura}

National Cancer Center Hospital: Kokuritsu Gan Kenkyu Center Chuo Byoin

\section{Miyu Kikuchi}

National Cancer Center Hospital: Kokuritsu Gan Kenkyu Center Chuo Byoin

\section{Koichi Ichimura}

Juntendo University Faculty of Medicine

Yoshitaka Narita ( $\nabla$ yonarita@ncc.go.jp)

National Cancer Center Hospital: Kokuritsu Gan Kenkyu Center Chuo Byoin https://orcid.org/00000003-4303-6006

\section{Research Article}

Keywords: Incidental, Glioblastoma, Clinical characteristics, Clinical outcomes

Posted Date: November 8th, 2021

DOI: https://doi.org/10.21203/rs.3.rs-1038263/v1

License: (c) (i) This work is licensed under a Creative Commons Attribution 4.0 International License. Read Full License 
Version of Record: A version of this preprint was published at Journal of Neuro-Oncology on January 5th, 2022. See the published version at https://doi.org/10.1007/s11060-021-03931-3. 


\section{Abstract \\ Objective}

With an increase in the number of imaging examinations and the development of imaging technology, a small number of glioblastomas (GBMs) are identified by incidental radiological images. These incidentally discovered glioblastomas (iGBMs) are rare, and their clinical features are not well understood. Here, we investigated the clinical characteristics and outcomes of iGBM.

\section{Methods}

Data of newly diagnosed iGBM patients who were treated at our institution between August 2005 and October 2019 were reviewed. An iGBM was defined as a GBM without a focal sign, discovered on radiological images obtained for reasons unrelated to the tumor. Kaplan-Meier analysis was performed to calculate progression-free survival (PFS) and overall survival (OS).

\section{Results}

Of 234 patients with newly diagnosed GBM, four (1.7\%) were classified as having iGBM. Health screening was the most common reason for tumor discovery (75.0\%). The preoperative Karnofsky performance status score was 100 in three patients. Tumors were found on the right side in three cases. The mean volume of preoperative enhanced tumor lesion was $16.8 \mathrm{~cm}^{3}$. The median duration from confirmation of an enhanced lesion to surgery was 13.5 days. In all cases, either total $(100 \%)$ or subtotal $(95-99 \%)$ resections were achieved. The median PFS and OS were 11.5 and 20.0 months, respectively.

\section{Conclusions}

The iGBMs were often small and in the right non-eloquent area, and the patients had good performance status. We found that timely therapeutic intervention provided iGBM patients with favorable outcomes. This report suggests that early detection of GBM may lead to a better prognosis.

\section{Introduction}

With increase in the number of imaging examinations and the development of imaging technology, incidental findings of intracranial neoplastic lesions have become more frequent in clinical situations. According to a systematic review of incidental brain findings on magnetic resonance imaging (MRI), the incidence of incidental neoplastic findings on head MRI, mainly meningioma, pituitary adenoma, and lower-grade glioma, was estimated to be $0.70 \%[1,2]$. In the past decade, the epidemiology and characteristics of incidental low-grade gliomas have been investigated. Incidental lower-grade gliomas account for 3.8-17.2\% of all lower-grade gliomas [3-6]. A lower-grade glioma is reported to grow slowly 
but steadily with $3.5 \mathrm{~mm} /$ year diametric expansion [3] or $3.9 \mathrm{~cm}^{3} /$ year volumetric increase [6]. The prognosis of incidental lower-grade glioma patients is better than that of symptomatic low-grade glioma patients, even when comparing complete resection groups [5]. In contrast to lower-grade gliomas, no study has investigated incidental high-grade glioma or glioblastoma. Therefore, their clinical and biological characteristics are poorly understood.

Glioblastoma (GBM) is the most life-threatening malignant brain tumor and is categorized as WHO grade IV. Even with the best treatment with maximal safe surgical resection following chemoradiotherapy with temozolomide, the median overall survival of GBM patients does not reach two years [7]. The representative prognostic factors of GBM patients include age, Karnofsky performance score (KPS), molecular diagnosis including isocitrate dehydrogenase 1 and 2 (IDH1/2) mutations and 0-6methylguanine deoxyribonucleic acid methyltransferase (MGMT) promoter methylation status, and the extent of initial surgical resection [8-14]. Additionally, a small preoperative contrast-enhanced tumor on imaging is an independent favorable prognostic factor [15]. These results indicate that early diagnosis with younger age, better performance status, and small tumor size may contribute to better outcomes in GBM patients.

This study retrospectively reviewed and investigated incidentally discovered GBM (iGBM) cases to determine their biological characteristics and clinical outcomes.

\section{Methods}

\section{Patient Selection}

This study was designed as a single-center retrospective analysis of a consecutive series of patients with GBM. First, adult GBM patients (age $\geq 18$ years) who were newly diagnosed and treated at our institution between August 2005 and October 2019 were identified. The patients had at least six months of postoperative follow-up. Patient data, including age, sex, clinical history, presurgical physical assessment, radiological images, surgical reports, and postsurgical clinical courses, were reviewed. Second, patients with iGBM were included in the study. The iGBM was defined as GBM, which was discovered by radiological images performed for reasons unrelated to the tumor, such as general clinical check-ups or unspecific headaches, which started to be treated within 6 months from the diagnosis. Patients who initially presented with headaches with any sign of increased intracranial pressure, such as nausea, vomiting, and any cerebral nerve symptoms, were excluded. All patients underwent surgical intervention within six months from the initial tumor discovery when gadolinium-enhanced mass lesions were confirmed on head MRI. The pathological diagnosis of glioblastomas was certified based on the 2007 or 2016 WHO classification of tumors of the central nervous system. The molecular profiles of the tumors, including IDH, telomerase reverse transcriptase (TERT), serine/threonine kinase B-RAF (BRAF), H3 histone, family $3 \mathrm{~A}(\mathrm{H} 3 \mathrm{~F} 3 \mathrm{~A})$ mutation status, and MGMT promoter methylation status, were extracted from medical records. The extent of resection was determined based on the surgeon's operative notes and on 
postoperative imaging studies, classified as either total if $100 \%$ of the enhanced lesion was resected, subtotal if $95-99 \%$ was resected, partial if $<94 \%$ was resected, or a biopsy.

\section{Molecular Analysis}

Tumor DNA was extracted from frozen tumor tissues for all cases using a DNeasy Blood \& Tissue Kit (Qiagen, Tokyo, Japan). The presence of hotspot mutations in IDH1 (R132) and IDH2 (R172) was assessed by pyrosequencing, as previously described [16]. Pyrosequencing assays were designed to detect all known mutations in these codons [16]. The two mutation hotspots in the TERT promoter were analyzed in all tumors by Sanger sequencing and/or pyrosequencing, as previously reported [17]. The mutation hotspots at codons 27 and 34 of H3F3A and codon 600 of BRAF were analyzed by Sanger sequencing and/or pyrosequencing [18]. The methylation status of the MGMT promoter was analyzed using bisulfite modification of the tumor genomic DNA, followed by pyrosequencing, as previously described [17]. Methylation was considered positive when its mean level at the $16 \mathrm{CpG}$ sites examined was greater than $16 \%[17,19]$.

\section{Statistical Analysis}

Overall survival (OS) was defined as the interval between the date of surgery and death. Progression-free survival (PFS) was defined as the interval between the date of surgery and the detection of progression. These times were calculated using the Kaplan-Meier method using GraphPad Prism 9 (GraphPad Software Inc., La Jolla, California, USA).

\section{Ethics Approval}

This study was conducted retrospectively using data obtained for clinical purposes. This study was approved by the Internal Review Board of the National Cancer Center (approval number: 2004-066).

\section{Result}

\section{Patient Demographics}

A total of 234 newly diagnosed GBM patients were treated at our institution between August 2005 and October 2019. Among them, four (1.7\%) were classified as having iGBM. The clinical characteristics of the four patients with iGBM are summarized in Table 1. The selected patients included three men and one woman, and their median age at the time of tumor discovery was 59.5 years old (range, 38-66 years). Health screening was the most common reason for tumor discovery $(75.0 \%, n=3)$, followed by nonspecific headaches $(25.0 \%, n=1)$. The tumors were first detected as enhanced lesions in patients 1,2 , 
and 3 and non-enhanced lesions in patient 4 (Fig. 1). Patient 4 was tightly followed by MRI and underwent surgical intervention when the tumor emerged as an enhanced lesion. The median duration from confirmation of an enhanced lesion to surgery was 13.5 days (range, 4-19 days). The preoperative KPS score was 100 in three patients (75.0\%) and 90 in one patient (25.0\%). Before surgery, patient 1 experienced minor left hemiparesis.

Table 1

Characteristics of patients with iGBM

\begin{tabular}{|llllll|}
\hline $\begin{array}{l}\text { Patient } \\
\text { No. }\end{array}$ & $\begin{array}{l}\text { Age } \\
\text { (yrs), } \\
\text { sex }\end{array}$ & $\begin{array}{l}\text { Mode of } \\
\text { discovery }\end{array}$ & Diagnosis & $\begin{array}{l}\text { Duration from confirmed enhanced } \\
\text { lesion to surgery }\end{array}$ & $\begin{array}{c}\text { Preop } \\
\text { KPS }\end{array}$ \\
\hline 1 & $62, \mathrm{~F}$ & $\begin{array}{l}\text { Health } \\
\text { check-up }\end{array}$ & $\begin{array}{l}\text { Glioblastoma, } \\
\text { IDH-wild }\end{array}$ & 4 days \\
\hline 2 & $57, \mathrm{M}$ & $\begin{array}{l}\text { Health } \\
\text { check-up }\end{array}$ & $\begin{array}{l}\text { Glioblastoma, } \\
\text { IDH-wild }\end{array}$ & 19 days \\
\hline 3 & $38, \mathrm{M}$ & $\begin{array}{l}\text { Health } \\
\text { check-up }\end{array}$ & $\begin{array}{l}\text { Glioblastoma, } \\
\text { IDH-wild }\end{array}$ & 100 \\
\hline 4 & $66, \mathrm{M}$ days & 100 \\
\hline KPS = Karnofsky performance score & $\begin{array}{l}\text { Headache } \\
\text { screening }\end{array}$ & $\begin{array}{l}\text { Glioblastoma, } \\
\text { IDH-wild }\end{array}$ & 18 days \\
\hline
\end{tabular}

\section{Tumor Characteristics}

The tumor characteristics and representative images are summarized in Table 2 and Figure 1. All tumors showed ring-enhanced lesions. The most common tumor location was the temporal lobe $(50.0 \%, n=2)$, followed by the parietal lobe $(25.0 \%, n=1)$ and frontal lobe $(25.0 \%, n=1)$. Tumors were found on the right side in three cases $(75.0 \%)$. The mean volume of preoperative enhanced tumor lesion was $16.8 \mathrm{~cm}^{3}$ (range, $2.2-23.6 \mathrm{~cm}^{3}$ ). 
Table 2

Characteristics of iGBM and the clinical outcomes

\begin{tabular}{|lllllllll|}
\hline Patient & Side & $\begin{array}{l}\text { Tumor } \\
\text { location }\end{array}$ & $\begin{array}{l}\text { Preop } \\
\text { tumor } \\
\text { volume }\end{array}$ & $\begin{array}{l}\text { Extent of } \\
\text { resection }\end{array}$ & $\begin{array}{l}\text { Postop } \\
\text { KPS }\end{array}$ & $\begin{array}{l}\text { PFS } \\
\text { from } \\
\text { surgery }\end{array}$ & $\begin{array}{l}\text { OS } \\
\text { from } \\
\text { surgery }\end{array}$ & Survival \\
\hline 1 & Right & $\begin{array}{l}\text { Parietal } \\
\text { lobe }\end{array}$ & $\begin{array}{l}22.6 \\
\mathrm{~cm}^{3}\end{array}$ & $\begin{array}{l}100 \% \text {, total } \\
\text { resection }\end{array}$ & 90 & $\begin{array}{l}3 \\
\text { months }\end{array}$ & $\begin{array}{l}17 \\
\text { months }\end{array}$ & Dead \\
\hline 2 & Right & $\begin{array}{l}\text { Temporal } \\
\text { lobe }\end{array}$ & $\begin{array}{l}23.6 \\
\mathrm{~cm}^{3}\end{array}$ & $\begin{array}{l}100 \% \text {, total } \\
\text { resection }\end{array}$ & 90 & $\begin{array}{l}13 \\
\text { months }\end{array}$ & $\begin{array}{l}23 \\
\text { months }\end{array}$ & Dead \\
\hline 3 & Right & $\begin{array}{l}\text { Temporal } \\
\text { lobe }\end{array}$ & $\begin{array}{l}19.0 \\
\mathrm{~cm}^{3}\end{array}$ & $\begin{array}{l}95 \%, \\
\text { Subtotal } \\
\text { total } \\
\text { resection }\end{array}$ & 90 & $\begin{array}{l}21 \\
\text { months }\end{array}$ & $\begin{array}{l}34 \\
\text { months }\end{array}$ & Alive \\
\hline 4 & Left & $\begin{array}{l}\text { Frontal } \\
\text { lobe }\end{array}$ & $\begin{array}{l}2.2 \\
\mathrm{~cm}{ }^{3}\end{array}$ & $\begin{array}{l}\text { 95\%, } \\
\text { Subtotal } \\
\text { total } \\
\text { resection }\end{array}$ & 90 & $\begin{array}{l}10 \\
\text { months }\end{array}$ & $\begin{array}{l}16 \\
\text { months }\end{array}$ & Dead \\
\hline KPS = Karnofsky performance score, PFS $=$ Progression-free survival, OS = Overall survival & \\
\hline
\end{tabular}

\section{Surgical Results, Molecular Diagnoses, and Adjuvant Therapies}

Three patients underwent surgery under general anesthesia, and one underwent awake surgery. Total resection of an enhancing lesion was achieved in two cases (50.0\%) and subtotal resection (95-99\% removal) in two cases (50.0\%). No postoperative mortality was observed. The median postoperative hospital stay was 18.0 days (range, 8-58 days). All patients were discharged with a KPS score of 90 . Histopathological diagnosis of GBM was confirmed in all cases. Molecular genetic examination revealed that no tumor had IDH1/2 mutation, two tumors (50.0\%) had TERT promoter mutation, one tumor (25.0\%) had BRAF mutation, and no tumor had H3F3A mutation; all tumors had low MGMT promoter methylation status. Following tumor resection, temozolomide $\left(75 \mathrm{mg} / \mathrm{m}^{2}\right.$ for seven days per week during radiotherapy, followed by $150-200 \mathrm{mg} / \mathrm{m}^{2}$ during six cycles of adjuvant therapy) was the most selected adjuvant chemotherapeutic agent and was used in three patients $(75.0 \%)$, and nimustine hydrochloride (100 $\mathrm{mg} /$ body) was used in one patient (25.0\%). Local brain radiotherapy (60 Gy in 30 fractions) was performed in all patients. No severe adverse effects were documented due to chemoradiotherapy.

\section{Outcomes}


All patients in this study had disease progression, and three patients died at the last follow-up. The median PFS and OS were 11.5 and 20.0 months, respectively (Fig. 2A and B).

\section{Discussion}

In this study, we demonstrate the clinical and genetic features of iGBMs. They are frequently located in the right hemisphere and in non-eloquent areas and received total or subtotal resection. Although iGBM exhibits unfavorable molecular characteristics, such as IDH-wildtype and MGMT promoter hypomethylation status, it demonstrated favorable clinical outcomes.

The initial signs and symptoms of glioblastoma depend on the location and size of the tumor. Headache (57.3\%) was the most common presenting symptom, followed by cognitive changes (38.8\%), language deficits (36.2\%), and motor deficits (35.9\%) [20]. Because there have been no reports of asymptomatic GBM patients, the proportion of asymptomatic patients at the initial presentation in the entire GBM population is still unknown.

This study revealed that iGBM accounted for $1.7 \%$ of patients with GBM during the examined period. The incidence may vary among countries and regions depending on the prevalence, resolution, and number of brain imaging performed annually. The brain screening system, familiarly named the "Brain Dock" system, is commercially and commonly available in Japan. This system was first established in 1988 to salvage non-symptomatic intracranial vascular diseases, including ischemic diseases and unruptured cerebral aneurysms [21], which costs approximately 500 US dollars. This system also contributes to the detection of asymptomatic brain tumors, including meningiomas, pituitary adenomas, and lower-grade gliomas. Based on these social and medical backgrounds, the incidence of iGBM in Japan is higher than the world average.

The laterality and size of the iGBM were unique. The iGBM is exceptionally lean on the right side. Generally, the laterality of GBM is symmetrical as $46-47 \%$ of them are right-sided, $42-48 \%$ are left-sided, and $6-12 \%$ are bilateral or at the central neuroaxis $[20,22]$. The tendency of right-sided iGBM is attributed to a functional difference in the left and right brain hemisphere; in $95-99 \%$ of right-handed individuals and $70 \%$ of left-handed individuals, the left cerebral hemisphere is the dominant hemisphere that controls language [23]. Therefore, tumors in the right hemisphere were less likely to be symptomatic than those on the left side. In addition, the small volume $\left(16.8 \mathrm{~cm}^{3}\right)$ of iGBM, compared to the mean GBM volume of $33.2 \mathrm{~cm}^{3}$ in a previous study [24], must contribute to the asymptomatic character of iGBM. On the other hand, the tumor location of iGBMs was similar to that of the GBM population; iGBM were found in the temporal, frontal, and parietal lobes, and according to past research, GBM is located at the frontal lobe in $43 \%$, and the temporal lobe in $28 \%$ [25]. Furthermore, the gender and age of iGBM are similar to those of general GBM; the incidence of GBM is $1.3-1.6$ higher in males than in females $[22,26-28]$ and the median age of diagnosis is $63-64$ years old $[22,26,27]$. The molecular status of iGBM $(100 \%$ of IDH wild 
type and $50.0 \%$ of TERT promoter mutation) almost agrees with the previous report of $10 \%$ IDH1/2 mutations and $74.2 \%$ TERT promoter mutation in GBM [28].

In this study, all iGBMs were removed via either total or subtotal resection. In general, gross or $100 \%$ total resection of GBM is only achieved in $20-43 \%$ of cases $[20,22]$. This favorable result might be due to the surgically optimal characteristics of iGBM, such as small volume and non-dominant hemisphere. Moreover, good perioperative physical and neurological conditions of iGBM patients contribute to tolerance to general anesthesia and complete chemoradiation therapy. As a result, the median PFS and OS of iGBM patients (11.5 and 20.0 months, respectively) were better than previous reports (6.3-7.1 months and 10.1-15.2 months) $[9,10,13,15,27]$. It is worth noting that the general patient demographics and molecular features of iGBM were not different from those of general GBM. In summary, iGBM patients have a great advantage in receiving timely therapeutic intervention when they are asymptomatic or before developing severe neurological deterioration.

The main limitation of this study is the small sample size due to the rarity of iGBM; therefore, our results need to be carefully interpreted. The majority of iGBM cases were identified by health screening. Patients who can afford to undergo health screening are considerably wealthy and health-conscious, thus having better physical conditions and broader treatment options. These factors may affect the clinical outcome of iGBMs.

\section{Conclusion}

We present a series of iGBM features, including clinical, radiological, molecular, and outcome data. The unique characteristics of iGBM provide a greater chance of tumor resection and consecutive chemoradiation therapy, which leads to a better prognosis.

The pathophysiology of GBM involves the rapid growth of the tumor and progression of neurological symptoms. Although finding a tumor by health screening is economically challenging, this report suggests that the prognosis of GBM may improve if it is diagnosed when the tumor is small and the symptoms are mild. Patients must consult a neurosurgeon or neurologist immediately when they become aware of neurological symptoms such as paralysis and aphasia.

\section{Declarations}

Funding: None to report

Author Contribution:

Conceptualization: Yoshitaka Narita; Methodology: Daisuke Kawauchi, Makoto Ohno, Yoshitaka Narita; Formal analysis and investigation: Daisuke Kawauchi, Makoto Ohno, Mai Honda-Kitahara, Koichi Ichimura; Writing - original draft preparation: Daisuke Kawauchi; Writing - review and editing: Makoto Ohno, Yoshitaka Narita; Funding acquisition: Yoshitaka Narita; Resources: Yoshitaka Narita; Supervision: 
Makoto Ohno, Yasuji Miyakita, Masamichi Takahashi, Shunsuke Yanagisawa, Yukie Tamura, Miyu Kikuchi, Koichi Ichimura, Yoshitaka Narita.

Data Availability: The datasets used and/or analyzed during the current study are available from the corresponding author on reasonable request.

Competing interests: All the authors have nothing to disclose except Dr. Ichimura and Dr. Narita. Dr. Ichimura reports grants from Chugai Pharmaceutical Co., Ltd., Eisai Co., Ltd., and Daiichi Sankyo Co.Ltd., outside the submitted work. Dr. Narita reports grants from Japan Agency for Medical Research and Development, Chugai Pharmaceutical co., MSD, Eisai, Toshiba, SBI pharma, Glaxo, Abbive, Ono, Stellapharma, Ohtuka, Meiji-seika, and Daiichi-Sankyo, outside the submitted work.

Previous Presentations: Any portion of the paper has not been presented previously.

\section{References}

1. Morris Z, Whiteley WN, Longstreth WT, Jr., Weber F, Lee YC, Tsushima Y, Alphs H, Ladd SC, Warlow C, Wardlaw JM, Al-Shahi Salman R (2009) Incidental findings on brain magnetic resonance imaging: systematic review and meta-analysis. BMJ 339: b3016 doi:10.1136/bmj.b3016

2. Neugut Al, Sackstein P, Hillyer GC, Jacobson JS, Bruce J, Lassman AB, Stieg PA (2019) Magnetic Resonance Imaging-Based Screening for Asymptomatic Brain Tumors: A Review. Oncologist 24: 375384 doi:10.1634/theoncologist.2018-0177

3. Pallud J, Fontaine D, Duffau H, Mandonnet E, Sanai N, Taillandier L, Peruzzi P, Guillevin R, Bauchet L, Bernier V, Baron MH, Guyotat J, Capelle L (2010) Natural history of incidental World Health Organization grade II gliomas. Ann Neurol 68: 727-733 doi:10.1002/ana.22106

4. Opoku-Darko M, Lang ST, Artindale J, Cairncross JG, Sevick RJ, Kelly JJP (2018) Surgical management of incidentally discovered diffusely infiltrating low-grade glioma. J Neurosurg 129: 1926 doi:10.3171/2017.3.JNS17159

5. Ius T, Cesselli D, Isola M, Pauletto G, Tomasino B, D'Auria S, Bagatto D, Pegolo E, Beltrami AP, Loreto CD, Skrap M (2020) Incidental Low-Grade Gliomas: Single-Institution Management Based on Clinical, Surgical, and Molecular Data. Neurosurgery 86: 391-399 doi:10.1093/neuros/nyz114

6. Gogos AJ, Young JS, Pereira MP, Morshed RA, Potts MB, Hervey-Jumper SL, Berger MS (2020) Surgical management of incidentally discovered low-grade gliomas. J Neurosurg: 1-8 doi:10.3171/2020.6.JNS201296

7. Stupp R, Mason WP, van den Bent MJ, Weller M, Fisher B, Taphoorn MJ, Belanger K, Brandes AA, Marosi C, Bogdahn U, Curschmann J, Janzer RC, Ludwin SK, Gorlia T, Allgeier A, Lacombe D, Cairncross JG, Eisenhauer E, Mirimanoff RO (2005) Radiotherapy plus concomitant and adjuvant temozolomide for glioblastoma. N Engl J Med 352: 987-996 doi:10.1056/NEJMoa043330

8. Lamborn KR, Chang SM, Prados MD (2004) Prognostic factors for survival of patients with glioblastoma: recursive partitioning analysis. Neuro Oncol 6: 227-235 
doi:10.1215/S1152851703000620

9. Weller M, Felsberg J, Hartmann C, Berger H, Steinbach JP, Schramm J, Westphal M, Schackert G, Simon M, Tonn JC, Heese O, Krex D, Nikkhah G, Pietsch T, Wiestler O, Reifenberger G, von Deimling A, Loeffler M (2009) Molecular predictors of progression-free and overall survival in patients with newly diagnosed glioblastoma: a prospective translational study of the German Glioma Network. J Clin Oncol 27: 5743-5750 doi:10.1200/JC0.2009.23.0805

10. Sanai N, Polley MY, McDermott MW, Parsa AT, Berger MS (2011) An extent of resection threshold for newly diagnosed glioblastomas. J Neurosurg 115: 3-8 doi:10.3171/2011.2.JNS10998

11. Marko NF, Weil RJ, Schroeder JL, Lang FF, Suki D, Sawaya RE (2014) Extent of resection of glioblastoma revisited: personalized survival modeling facilitates more accurate survival prediction and supports a maximum-safe-resection approach to surgery. J Clin Oncol 32: 774-782 doi:10.1200/JCO.2013.51.8886

12. Brown TJ, Brennan MC, Li M, Church EW, Brandmeir NJ, Rakszawski KL, Patel AS, Rizk EB, Suki D, Sawaya R, Glantz M (2016) Association of the Extent of Resection With Survival in Glioblastoma: A Systematic Review and Meta-analysis. JAMA Oncol 2: 1460-1469 doi:10.1001/jamaoncol.2016.1373

13. Vand Rajabpour M, Yahyazadeh H, Beheshti M (2017) Prognostic Factors and Survival of Glioblastoma Multiform (GBM) in Iranian Patients. International Journal of Cancer Management 10 doi:10.5812/ijcm.6260

14. Molinaro AM, Hervey-Jumper S, Morshed RA, Young J, Han SJ, Chunduru P, Zhang Y, Phillips JJ, Shai A, Lafontaine M, Crane J, Chandra A, Flanigan P, Jahangiri A, Cioffi G, Ostrom Q, Anderson JE, Badve C, Barnholtz-Sloan J, Sloan AE, Erickson BJ, Decker PA, Kosel ML, LaChance D, Eckel-Passow J, Jenkins R, Villanueva-Meyer J, Rice T, Wrensch M, Wiencke JK, Oberheim Bush NA, Taylor J, Butowski N, Prados M, Clarke J, Chang S, Chang E, Aghi M, Theodosopoulos P, McDermott M, Berger MS (2020) Association of Maximal Extent of Resection of Contrast-Enhanced and Non-ContrastEnhanced Tumor With Survival Within Molecular Subgroups of Patients With Newly Diagnosed Glioblastoma. JAMA Oncol 6: 495-503 doi:10.1001/jamaoncol.2019.6143

15. Li YM, Suki D, Hess K, Sawaya R (2016) The influence of maximum safe resection of glioblastoma on survival in 1229 patients: Can we do better than gross-total resection? J Neurosurg 124: 977-988 doi:10.3171/2015.5.JNS142087

16. Arita H, Narita Y, Matsushita Y, Fukushima S, Yoshida A, Takami H, Miyakita Y, Ohno M, Shibui S, Ichimura K (2015) Development of a robust and sensitive pyrosequencing assay for the detection of IDH1/2 mutations in gliomas. Brain Tumor Pathol 32: 22-30 doi:10.1007/s10014-014-0186-0

17. Arita H, Narita Y, Fukushima S, Tateishi K, Matsushita Y, Yoshida A, Miyakita Y, Ohno M, Collins VP, Kawahara N, Shibui S, Ichimura K (2013) Upregulating mutations in the TERT promoter commonly occur in adult malignant gliomas and are strongly associated with total 1p19q loss. Acta Neuropathol 126: 267-276 doi:10.1007/s00401-013-1141-6

18. Arita H, Yamasaki K, Matsushita Y, Nakamura T, Shimokawa A, Takami H, Tanaka S, Mukasa A, Shirahata M, Shimizu S, Suzuki K, Saito K, Kobayashi K, Higuchi F, Uzuka T, Otani R, Tamura K, 
Sumita K, Ohno M, Miyakita Y, Kagawa N, Hashimoto N, Hatae R, Yoshimoto K, Shinojima N, Nakamura H, Kanemura Y, Okita Y, Kinoshita M, Ishibashi K, Shofuda T, Kodama Y, Mori K, Tomogane Y, Fukai J, Fujita K, Terakawa Y, Tsuyuguchi N, Moriuchi S, Nonaka M, Suzuki H, Shibuya M, Maehara T, Saito N, Nagane M, Kawahara N, Ueki K, Yoshimine T, Miyaoka E, Nishikawa R, Komori T, Narita Y, Ichimura K (2016) A combination of TERT promoter mutation and MGMT methylation status predicts clinically relevant subgroups of newly diagnosed glioblastomas. Acta Neuropathol Commun 4: 79 doi:10.1186/s40478-016-0351-2

19. Ohno M, Miyakita Y, Takahashi M, Igaki H, Matsushita Y, Ichimura K, Narita Y (2019) Survival benefits of hypofractionated radiotherapy combined with temozolomide or temozolomide plus bevacizumab in elderly patients with glioblastoma aged >/= 75 years. Radiat Oncol 14: 200 doi:10.1186/s13014019-1389-7

20. Chang SM, Parney IF, Huang W, Anderson FA, Jr., Asher AL, Bernstein M, Lillehei KO, Brem H, Berger MS, Laws ER, Glioma Outcomes Project I (2005) Patterns of care for adults with newly diagnosed malignant glioma. JAMA 293: 557-564 doi:10.1001/jama.293.5.557

21. Morita A (2019) Value of Brain Dock (Brain Screening) System in Japan. World Neurosurg 127: 502 doi:10.1016/j.wneu.2019.04.211

22. (2017) Brain Tumor Registry of Japan (2005-2008). Neurol Med Chir (Tokyo) 57: 9-102 doi:10.2176/nmc.sup.2017-0001

23. Corballis MC (2014) Left brain, right brain: facts and fantasies. PLoS Biol 12: e1001767 doi:10.1371/journal.pbio.1001767

24. Awad AW, Karsy M, Sanai N, Spetzler R, Zhang Y, Xu Y, Mahan MA (2017) Impact of removed tumor volume and location on patient outcome in glioblastoma. J Neurooncol 135: 161-171 doi:10.1007/s11060-017-2562-1

25. Simpson JR, Horton J, Scott C, Curran WJ, Rubin P, Fischbach J, Isaacson S, Rotman M, Asbell SO, Nelson JS, Weinstein AS, Nelson DF (1993) Influence of location and extent of surgical resection on survival of patients with glioblastoma multiforme: Results of three consecutive radiation therapy oncology group (RTOG) clinical trials. International Journal of Radiation Oncology*Biology*Physics 26: 239-244 doi:10.1016/0360-3016(93)90203-8

26. Ostrom QT, Gittleman H, Farah P, Ondracek A, Chen Y, Wolinsky Y, Stroup NE, Kruchko C, BarnholtzSloan JS (2013) CBTRUS statistical report: Primary brain and central nervous system tumors diagnosed in the United States in 2006-2010. Neuro Oncol 15 Suppl 2: ii1-56 doi:10.1093/neuonc/not151

27. Thakkar JP, Dolecek TA, Horbinski C, Ostrom QT, Lightner DD, Barnholtz-Sloan JS, Villano JL (2014) Epidemiologic and molecular prognostic review of glioblastoma. Cancer Epidemiol Biomarkers Prev 23: 1985-1996 doi:10.1158/1055-9965.EPI-14-0275

28. Killela PJ, Pirozzi CJ, Healy P, Reitman ZJ, Lipp E, Rasheed BA, Yang R, Diplas BH, Wang Z, Greer PK, Zhu H, Wang CY, Carpenter AB, Friedman H, Friedman AH, Keir ST, He J, He Y, McLendon RE, Herndon JE, 2nd, Yan H, Bigner DD (2014) Mutations in IDH1, IDH2, and in the TERT promoter define clinically 
distinct subgroups of adult malignant gliomas. Oncotarget 5: 1515-1525 doi:10.18632/oncotarget.1765

\section{Figures}

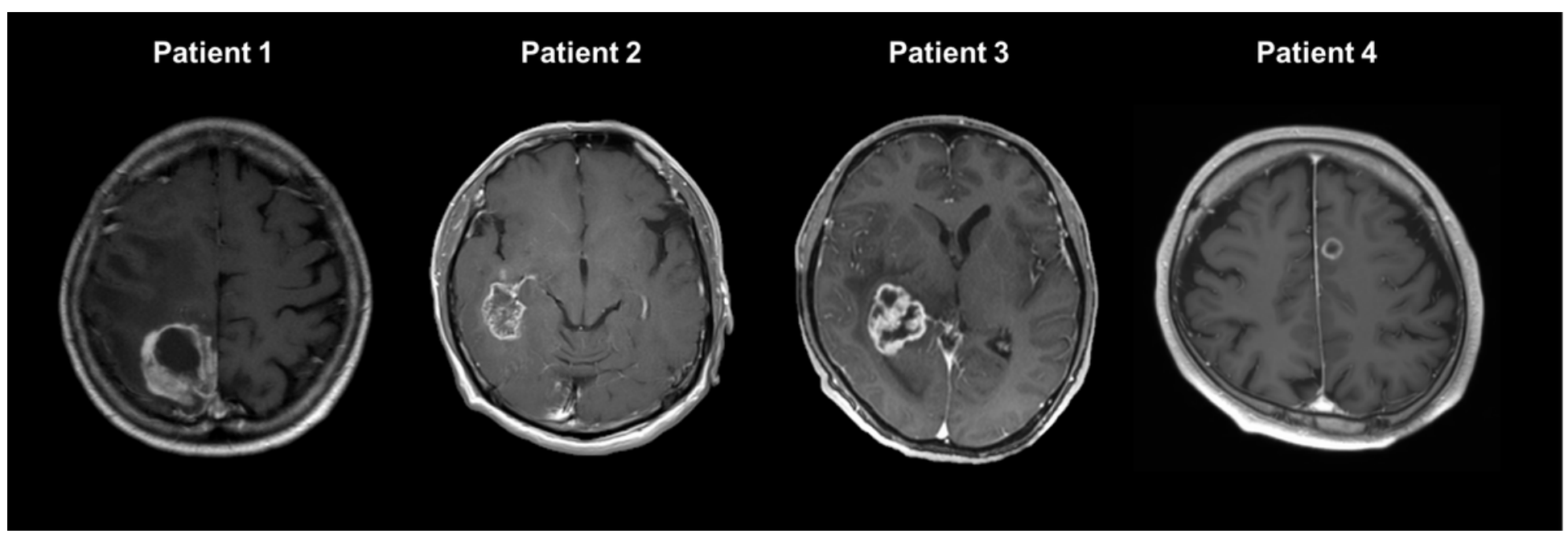

\section{Figure 1}

Axial gadolinium-enhanced T1-weighted MR images obtained in iGBM patients. 
(A)

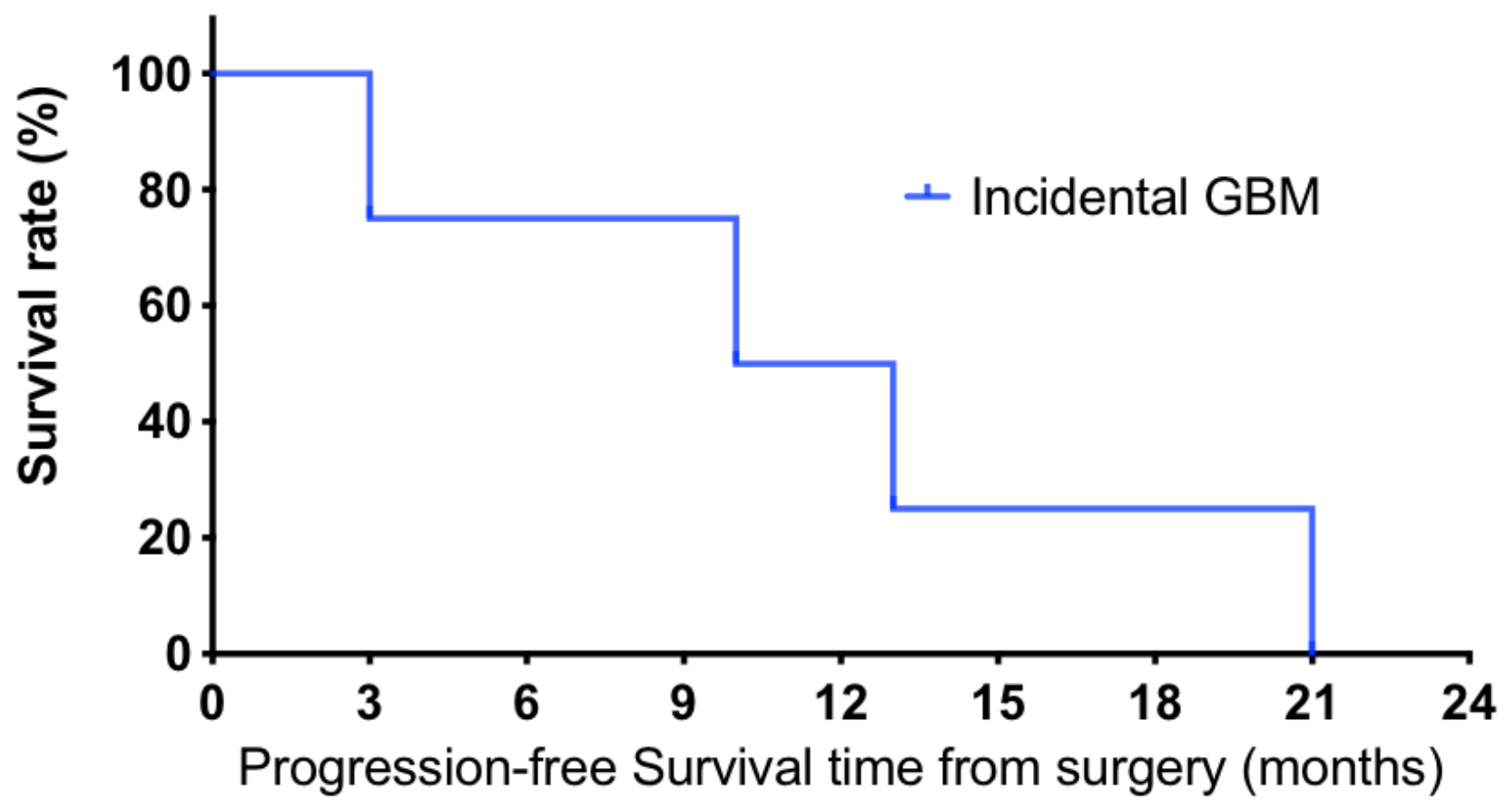

(B)

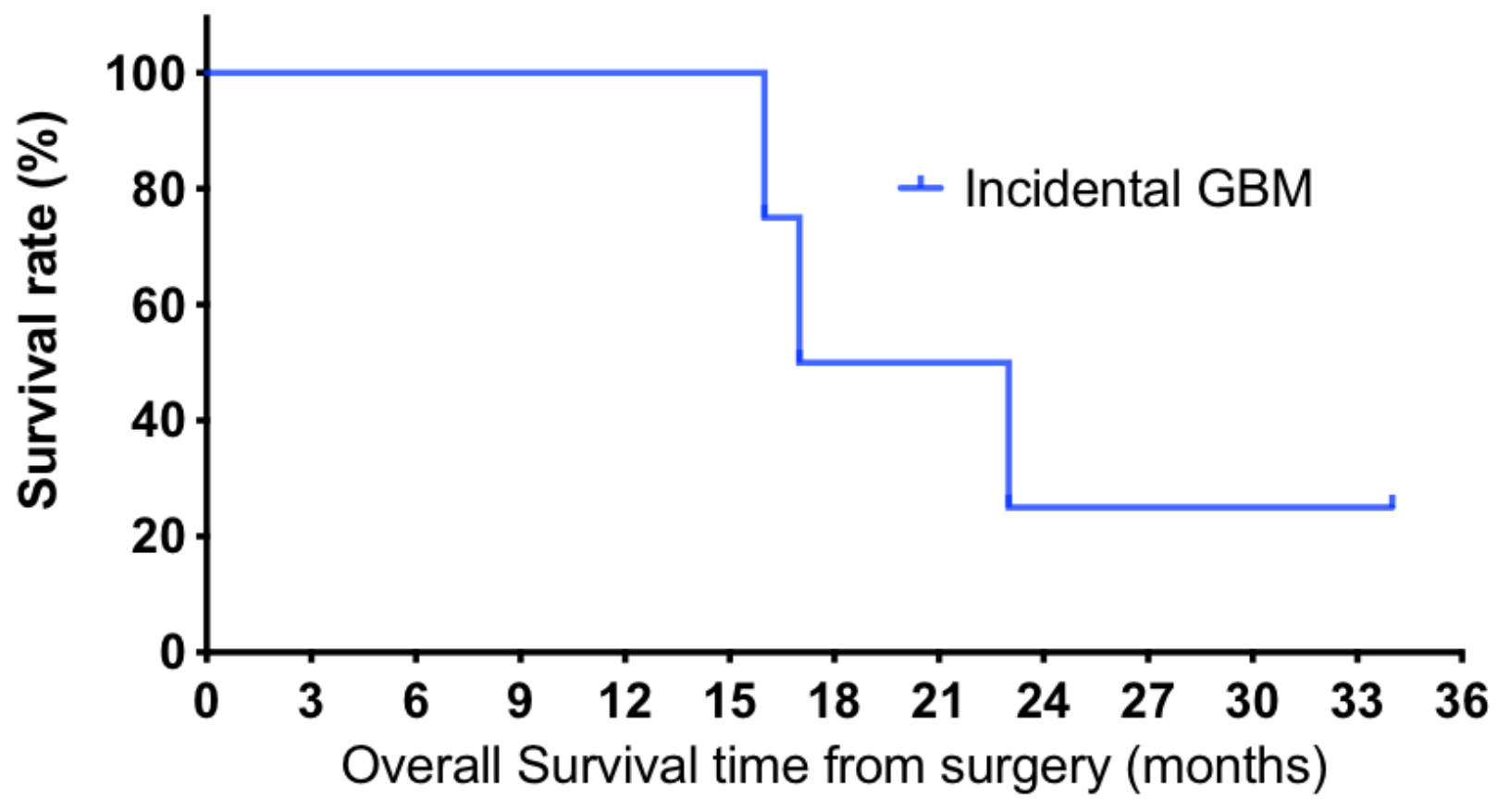

Figure 2

Kaplan-Meier curves for PFS (A) and OS (B) in patients with incidental GBM. 